\title{
Needs Analysis Blended Laboratory in The Context of the Adequacy of Supporting Facilities for Science Learning Using the Internet of Things and Augmented Reality
}

\author{
Dadan Rosana $^{1 *}$, Supahar $^{2}$, Sukardiyono $^{3}$ \\ ${ }^{1}$ Study Program of Science Education, Faculty of Mathematics and Natural Sciences, Universitas Negeri Yogyakarta \\ 2,3Study Program of Physics Education, Faculty of Mathematics and Natural Sciences, Universitas Negeri Yogyakarta \\ ${ }^{+}$Corresponding Author: danrosana@uny.ac.id
}

\section{Keywords: \\ blended laboratory, laboratory \\ facilities, IoT, AR}

\begin{abstract}
The blended laboratory model in this study refers to an integrated laboratory concept combining synchronous (real laboratory activities) using the Internet of things (IoT) and asynchronous learning with augmented reality (AR). The application of blended laboratory model in science learning teachers is still low in Indonesia due to the lack of ICT support for online learning. This preliminary study was conducted to analyze the need for the development of the blended laboratory model with IoT and AR involving 45 science teachers and 42 junior high school students as the respondents with stratified random sampling technique. The research method employed survey and focus group discussion. The results of the study showed that (1) $67 \%$ of teachers and $92 \%$ of students have never used AR, (2) $72 \%$ of teachers and $89 \%$ of students have never utilized IoT, (3) $65 \%$ of science laboratories in the junior high school do not have proper devices for AR application, (5) $76 \%$ of science laboratories in the junior high schools are not facilitated with proper equipment for the IoT application, (6) the respondents stated that the development of blended laboratory is very important $(72 \%)$ and important $(18 \%)$ to support IT-based learning, especially to deal with the conditions after the Covid-19 outbreak.
\end{abstract}

\section{INTRODUCTION}

Covid-19 outbreak occurs along with the disruption era of the Industrial revolution 4.0 and society 5.0 that escalated the massive use of digital technology among the community and learning activities throughout the world including Indonesia. According to Jackman (Sharma \& Thanaya, 2016), this 4.0 revolution era cannot be separated from the rapid ICT development since technology plays crucial role in this shift of sociocultural quantum. Currently, technology has totally changed the way of people life, such as the learning process. The teachers' duties are now to balance skill building with technology, core principles and suitable learning experiences for optimal students' development (Keoh et al., 2014).

The challenge of science learning in the future is how to optimize ICT as part of the media that is needed both during and post Covid-19 pandemic. In addition, to anticipate the demands of the era of disruption, we need the partnership for the 21st century which can be identified from the four "Learning and Innovation skills" consisting of creativity, critical thinking, communication, collaboration (Bishop, 2017). This disruption era, 
education is in the knowledge age with an extraordinary acceleration for knowledge that must be supported by the application of digital media and technology called the information superhighway. The learning activity model in the knowledge age must be adapted to the future needs among students. It means that the learning materials should be designed to be more authentic related to support the in solving their learning problems. Problem solving leads students to searches answers and find solution within the learning context utilizing available information resources (Trilling \& Hood, 1999). Teachers are challenged to provide creativity in learning process through examples and direct practice where they teachers act as a model of creative behavior. With a supportive environment, students will be able to make connections between learning materials and the surrounding environment through the appropriate learning designs (Seidel et al., 2009). This demand has raised the urgency of the integrated laboratory model

The blended laboratory model is a term proposed by the researchers to put forwards the concept that combine between realistic laboratory activities (synchronous) using multisensory based Internet of Things (IoT) with the MQTT protocol and virtual laboratory activities using augmented reality (asynchronous). The concept of blended laboratory is inspired by a recent issue that is relevant to this research, i.e., blended learning. This model is very important to be developed as part of Indonesia's efforts to catch up in the field of science and technology learning among the other developed countries. The systematic efforts based on clear achievement indicators are needed, one of which is the development of this research as a network system that connects science laboratories with internet networks and sensor systems to obtain relevant data information of science learning in real time. This system is divided into two parts, wireless sensor nodes and IoT (Sharma \& Thanaya, 2016).

In general, IoT can be interpreted as the connection of various surrounding objects through an internet network. Here, IoT requires a communication line that suits the needs of the system like the MQTT protocol (Chrisyantar et al., 2018) to provide realistic practical learning in the science field to be more meaningful and complete. IoT as a scientific development is very promising to optimize the quality of life including education based on smart sensors and smart devices that work together through the internet network (Keoh et al., 2014). With the large number of things/objects and sensors/actuators connected to the internet, massive and real-time (in some cases) data streams will be automatically generated by the connected things and sensors. Of all the activities that exist in IoT is to collect the correct raw data in an efficient way but the analysis and the processing of raw data into more valuable information is the most valuable (Wang et al., 2013).

Although the characteristics of science learning are hands-on investigations of natural phenomena, but the Covid-19 pandemic situation and the rapid development of digital technology drive to develop a virtual practicum using Augmented Reality (AR). The AR applications for laboratory activities are designed in 3-Dimensional (3D) object recognition. This AR technology is used to provide direction or guidance to students in the form of integrated science practicums (Biology, Physics, and Chemistry) with the virtual 3D object innovations that are displayed, not only to be seen but also sensed. Users can use smartphones to track a cube that is specially designed to display 3D Science objects (Wahyudi \& Andria, 2018). The unity of 3D can also be used to create other interactive content, such as architectural visuals and real-time 3D animation. Apart from being a game engine, tis unity of 3D can also be used as an editor for the existing games (Rahman, 2014).

The problem that needs to be anticipated related to the application of a blended laboratory is the supporting ICT facilities and infrastructure in a laboratory. It means a need analysis of blended laboratory must be done related to the adequacy of the supporting facilities for science learning with the IoT and AR. The purpose of this needs analysis is not to determine the urgency to develop a blended laboratory because it will be a crucial factor for the future demands, particularly in science practical course in junior high schools. This need analysis was carried out to obtain a map of the ICT which was required by the science laboratories of junior high schools in Indonesia related to the application of blended learning for practical activities. The need analysis is also needed as a policy recommendation for partner schools that collaborate with the research team in developing and testing the blended laboratory model.

\section{METHOD}

This research belongs to a quantitative research with descriptive survey method. According to Moleong (2012), descriptive data is in the form of written or oral descriptions of people and observable behavior. Similarly, Sugiyono (2014) highlights that, in the survey method, the researchers collected data by distributing questionnaires where the researchers did not give treatment as in the experiment. Questionnaires are used to obtain data from certain natural populations. Kusumawati (2015) explains that descriptive qualitative research requires data in the form of words and documentation (photos, videos, tapes, memos, personal documents, official 
documents, other documents) which are obtained from interviews and field notes.

In this descriptive quantitative study, the collected data was in the form of a scale based on the perceptions of teacher and student as the respondents that illustrated the readiness of the science laboratory in junior high school to implement the application of blended laboratory learning with IoT and AR. The sampling technique was a probability sample technique with proportionate stratified random sampling. Proportionate stratified random sampling refers to a technique or method of taking sample members from a population that is not homogeneous and stratified proportionally (Sugiyono, 2014). The different populations number in each school became the reason for taking sample members with proportionate stratified random sampling.

This research was conducted by analyzing the needs of the science laboratory in junior high school that had not owned the facilities to develop IoT and AR learning for blended learning model in science practicum in junior high school. The population in this study were 7th, 8th, and 9th grade students from 12 junior high schools through online survey. The determination of the samples number referred to the Isaac and Michael table with the 5\% error rate which resulted in a total sample of 45 teachers and 42 students as the respondents.

There were two kinds of variables in this study, the availability of laboratory facilities to support the application of AR and IoT and the teachers' readiness in mastering ICT to support the practical learning using the blended learning concept. The availability of facilities in this study includes availability of internet network, computers with minimum specifications that can be connected to AR and IoT applications and supporting devices to implement virtual laboratories.

The obtained data based on the survey regarding the need for the development of the blended laboratory model were calculated using the following formulas, while the data from observations, interviews and documentation were analyzed descriptively.

$$
\%=\frac{n}{N} \times 100 \%
$$

$\mathrm{n}=$ gain scores from the respondent

$\mathrm{N}=$ maximum scores from the respondent

$\%=$ Percentage

(Suharsimi Arikunto,2009:236).

\section{RESULT}

The Covid-19 pandemic has lasted for almost 2 years and demanded the development of a hybrid learning/blended learning/mixed method learning model. In practical activities, this model combines two learning activities, namely synchronous and asynchronous which requires students to learn by utilizing various teaching materials, such as print, audio/visual and network-assisted, as well as joining online practicums.

The blended laboratory model in this study employed an integrated laboratory activity concept that mixed the realistic laboratory activities (synchronous) using the Internet of things (IoT) and asynchronous activities using augmented reality (AR). The application of blended learning for practical activities in the science laboratory seems low in Indonesia. One of the main causes is the lack of ICT support in the laboratory for online learning. This preliminary study involving science teachers and junior high school students as the respondents to analyze the need for the development of the blended laboratory model in the context of the adequacy of supporting facilities for science learning using the IoT and AR.

Based on the initial questionnaire that had been completed by the science teachers and the students, the several results can be presented as follows. The majority of teacher and student respondents are not familiar with AR and IoT technology. The results of the study show that (1) $67 \%$ of teachers and $92 \%$ of students have never used AR, (2) $72 \%$ of teachers and $89 \%$ of students have never used IoT.

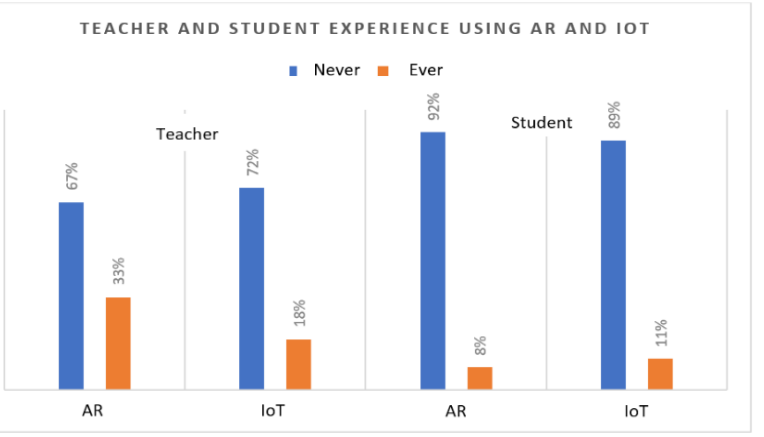

Figure 1. Techers and Students Experiences in Using AR dan IoT

Though in the pandemic situation, practicum activities must go on because it is very important to develop science process skills and students' concepts understanding. Decaprio (2013:16) mentions that the laboratory is a place for a group of people who carry out various research activities, observation, training and scientific testing as an approach between theory and practice from any disciplines. It shows that for whatever reasons the laboratory activities should be continued although in an online system. It indicates that AR and IoT technology are very appropriate to be mastered by science teachers and junior high school students in this current situation.

Hawkins \& Phelps (2013) clarifies that a virtual laboratory can be used instead of a real laboratory because it produces an understanding that is quite similar. The use of virtual laboratories is still rare in Indonesia, especially in science subjects, so it needs to be developed and studied further. Virtual laboratories are claimed to be able to improve student 
learning achievements, such as cognitive achievement and scientific attitudes (Tüysüz, 2010).

There are minimum requirements of the IT facilities to implement virtual laboratories. Based on the survey results, it was found that $65 \%$ science laboratories of junior high school do not have appropriate equipment for the AR application, and $76 \%$ for IoT application. The minimum specifications to run the blended laboratory model in the junior high school level is presented in Table 1 below.

Table 1. The minimum infrastructure to run blended laboratory system

\begin{tabular}{l} 
Minimum Specification for IT Software \\
\hline Specification for AR \\
1. CPU: Intel Core i5 4590 / AMD Ryzen 51400 \\
2. GPU: NVIDIA GTX 1060 / AMD RX $470 / 570$ or \\
greater \\
3. RAM: 8 GB \\
4. OS: Windows 10 October 2018 or newer \\
5. Ports: 1x HDMI 2.0 or DisplayPort + 1x USB 3.0 \\
port \\
6. Bluetooth 4.0 \\
Specification for IoT \\
1. the application can be installed on Android devices. \\
2. the system can only be accessed via the .apk format \\
file that has been installed on the Android device. \\
3. The application can be run on at least Android \\
version 4.2 (Jellybean). \\
4. Simple user interface to assist the users
\end{tabular}

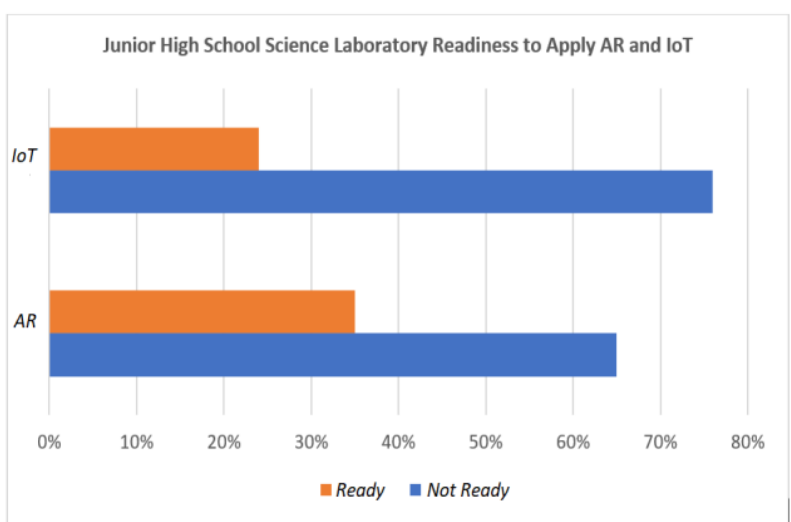

Figure 2. The Readiness of Science Laboratory Infrastructure to implement a blended laboratory for science practical learning

The existence of a virtual laboratory is the most practical learning alternative during this pandemic condition. Mintz (1993) states that computer simulation can enhance students' motivation and desire to learn science. Similarly, Roth \& Choudhury (1993) emphasize that computer simulation can activate students' science processing skills. Lazarowitz \& Huppiq (1993) agree that computer simulation can improve students' science process skills which is in line with the opinion of Lavoie \& Good (1988) that computer simulation can improve predictive skills where computer simulation proved to be an effective tool to improve students' hypothesis formulation, graph interpretation and prediction skills. Sahin (2006) also recommend further research using computer simulations for distance education laboratories. Lindgreen and Schwartz (2009) add that four things from the latest simulation design that influence vivid learning are image quality, attention grabbing, structure, and sound.

In addition to supporting infrastructure for the implementation of virtual laboratories, researchers also need to look at the responses of teacher and student respondents regarding the importance of learning using AR and IoT technology for science learning. The results show that $77 \%$ of respondents stated that it was very important and $18 \%$ important about the development of a blended laboratory model to support IT-based learning, especially to anticipate conditions after the Covid-19 pandemic.

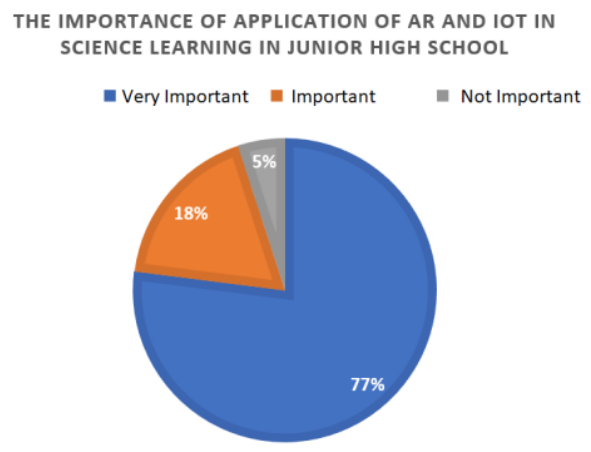

Figure 3 . The percentage on the perception among teachers and students on the importance of IoT and AR for Practical Science Leaning in Junior High School

Theory and practice in science learning must be in line. It means that the theoretical learning and the laboratory practicum must run side by side. The application of ICT in science teaching like VR-based laboratories is very meaningful for demonstration (Bakar et al., 2013). A virtual laboratory can be used instead of a real laboratory because it can provide similar understanding among students (Hawkins \& Phelps, 2013). In fact, virtual laboratories are claimed to be able to improve students' learning achievements, such as cognitive achievement and scientific attitudes (Tüysüz, 2010). These two variables are used as variables in this study because, theoretically, scientific attitude is students' internal factor that has a positive correlation with student achievement (Sihombing, 2016). It means that the higher scientific attitude, the better learning achievements will be obtained by students (Martasari et al., 2012).

\section{CONCLUSION}

A virtual laboratory can be used as a substitute for real laboratory settings because it can present a 
similar understanding among students. That is why, it should be developed optimally, and, for this reason, a need analysis has been carried out regarding the development of a virtual laboratory. The results of the study showed that (1) $67 \%$ of teachers and $92 \%$ of students have never used AR, (2) $72 \%$ of teachers and $89 \%$ of students have never utilized IoT, (3) $65 \%$ of science laboratories in the junior high school do not have proper devices for AR application, (5) 76\% of science laboratories in the junior high schools are not facilitated with proper equipment for the IoT application, (6) the respondents stated that the development of blended laboratory is very important (72\%) and important (18\%) to support IT-based learning, especially to deal with the conditions after the Covid-19 outbreak

\section{ACKNOWLEDGMENTS}

We thank to the Directorate of Research and Community Service, Ministry of Education, Culture, Research and Technology of Indonesia for the support of research funds under the contract number 289/E4.1/AK.04.PT/2021. Our gratitude also goes to the Research and Community Service Institute of UNY for its monitoring, evaluation, and quality assurance.

\section{REFERENCES}

Ariana, Yoki dkk, (2018). Pegangan Pembelajaran Berorientasi pada Keterampilan Berpikir Tingkat Tinggi, Jakarta: Dirjend GTK Kemdikbud.

Arikunto. 2013. Dasar-dasar Evaluasi Pendidikan. Jakarta: Rineka Cipta.

Bandyopadhyay, S. \& Bhattacharyya, A. (2013). Lightweight Internet Protocols for Web Enablement of Sensors using Constrained Gateway Devices. International Conference on Computing, Networking and Communications, Workshops Cyber Physical System, 28-31 January, San Diego, US. 334340.

Bakar, A., 2012, Kedokteran Gigi Klinis, 2nd ed, Yogyakarta, Penerbit Quantum Sinergis Media, p. 200

Bishop, J., \& Ph, D. (2017). 21st Century Skills (P21)

Cennamo, K. \& Kalk, D. (2005). Real World Instructional Design. Diambil tanggal 8 Agustus 2020 dari www.Amazon.com.

Chrisyantar Hasiholan, Rakhmadhany Primananda, \& Kasyful Amron. (2018). Implementasi Konsep Internet of Things pada Sistem Monitoring Banjir menggunakan Protokol MQTT. Jurnal Pengembangan Teknologi Informasi dan Ilmu Komputer. 2(12): 61286135
Decaprio, Richard. 2013. Tips Mengelola Laboratorium Sekolah. Yogyakarta: Diva Press.

Efendi, Yoyon. (2018). Internet of Things (IoT) Sistem Pengendalian Lampu Menggunakan Raspberry Pi Berbasis Mobile. Jurnal Ilmiah Ilmu Komputer. 4(1): 19-26

Hawkins, I., \& Phelps, A. (2013). Virtual laboratory vs. traditional laboratory: which is more effective for teaching electrochemistry? Chemistry Education Research and Practice, 14(4), 516-523. doi:10.1039/c3rp00070b

Howstuffworks (2014), Head Mounted Displays | electronics.howstuffwors.com [online] Tersedia di: http://electronics.howstuffworks.com/ gadgets/other-gadgets/VR-gear1.htm [Accessed 31 Jan 2017]

Keoh, S. L., Kumar, S., \& Tschofenig, H. (2014). Securing the Internet of Things: A Standardization Perspective. IEEE Internet of Things Journal, 1(3), 1-1. http://doi.org/10.1109/JIOT.2014.2323395

Kurniati, Dian. (2016). Kemampuan Berpikir Tingkat Tinggi Siswa SMP Di Kabupaten Jember Dalam Menyelesaikan Soal Berstandar PISA. Jurnal Penelitian dan Evaluasi Pendidikan 20(2), 142-155.

Kusumawati, Mia. (2015). Penelitian pendidikan penjasorkes. Bandung: Alfabeta.

Lavoe, D. R., \& Good. R. (1988). The Nature and Use of Prediction Skills in a Biological Computer Simulation. Journal of Research in Science Teaching, 25.335-60.

Lazarowitz, R.. \& Huppiq J. (1993). "science Process Skills of 10 'hgrade Biolory Students in a Computer-Assisted Learning Setting." Journal of Computing In Education, 25,366-382.

Lindgreen, R. and Schwartz, D.L.(2009).Spatial Learning and Computer Simulation in Science. International Journal of Science Education. 3 $1,(2), 419-438$

Maretasari, E. (2012). Penerapan model pembelajaran inkuiri terbimbing berbasis laboratorium untuk meningkatkan hasil belajar dan sikap ilmiah peserta didik. Unnes Physics Education Journal, 1(2): 27- 31.

Maryati, Sri., (2015). Dinamika Pengangguran Terdidik: Tantangan Menuju Bonus Demografi Di Indonesia. Journal of Economic and Economic Education Vol.3 (2). Hal.124 136

Mintz, R. (1993). Computerized Simulation as an Inquiry Tool. School Science and Mathematics, 93(2), 76-80. Retrieved October 4 ,

from https://www.learntechlib.org/p/147180/ 
Moleong, Lexy J. (2012). Metodologi Penelitian Kualitatif. Bandung: PT Remaja Rosdakarya.

Paul Milgram \& Fumio Kishino (1994). A Taxonomy of Mixed Reality Visual Displays. IEICE Transactions on Information Systems, Vol E77-D, No.12.

Rahman, Abdur. (2014). "Rancang Bangun Aplikasi Informasi Universitas Bengkulu Sebagai Panduan Pengenalan Kampus Menggunakan Metode Markerless Augmented Reality Berbasis Android". Jurnal Rekursif. 2(2): 67

Rochman, H. A., Primananda, R. \& Nurwasito, H. (2017). Sistem Kendali Berbasis Mikrokontroler menggunakan Protokol MQTT pada Smarthome. Fakultas Ilmu Komputer Universitas Brawijaya, Malang.

Roth, W. M., Roychoudhury. A. (1993). The Development of Science Process Skills in Authentic Context. Journal of Research in Science Teaching, 30, 127 -1 52.

Sahin, S. (2006). Computer Simulations in Science Education: Implications for Distance Education. Turkish Online Journal of Distance Education 7(4), 132-146.

Saputra, Hatta. (2016). Pengembangan Mutu Pendidikan Menuju Era Global: Penguatan Mutu Pembelajaran dengan Penerapan HOTS (High Order Thinking Skills). Bandung: SMILE's Publishing.

Sharma, N., \& Thanaya, I. (2016). Home Security System Based on Sensor And IOT. International Jurnal of Innovative Research in Science Engineering and Technology, 1. (2): 43-52

Seidel, S., Tishman, S., Winner, E., Hetland, L., \& Palmer, P. (2009). The qualities of quality: Understanding excellence in arts education. Cambridge: MA: Project Zero, Harvard Graduate School of Education. Retrieved from http://www.wallacefoundation.org/knowledge -center/Documents/

UnderstandingExcellence-in-Arts-

Education.pdf.

Sugiyono. 2014. Metode Penelitian Kombinasi (Mix Methods). Bandung: Alfabeta.

Theresia, (2018). Analisis Penerapan Suistanable Development Goals (SDGs) pada Beberapa Anggota Indonesia Global Compact Network $(I G C N)$. National Conference of Creative Industry: Sustainable Tourism Industry for Economic Development. Hal. 941-951.

Trilling, B. dan Hood. P. (1999). Learning, Technology, and Education Reform in the. Knowledge Age. USA: Educational Technology.

Tüysüz, C. (2010). The Effect of the Virtual Laboratory on Students' Achievement and
Attitude in Chemistry. International Online Journal of Educational Sciences, 2, 37-53.

Utomo, D.S., Arwani, I., Wardhono, W.S. (2017). Implementasi Mobile Augmented Reality Pada Aplikasi Pemilihan Sarana Dan Prasarana Laboratorium Sekolah Menengah Atas. Jurnal Pengembangan Teknologi Informasi dan Ilmu Komputer. 1(3): 224-235

Ulfah \& Arini Hidayati, (2017). Melatih Keterampilan Berpikir Tingkat Tinggi Dalam Pembelajaran Matematika Pada Siswa Sekolah Dasar, Jurnal Pendidikan dan Pembelajaran Dasar Terampil. Vol. 4 Nomor 2 Oktober 2017: 147

Umar, Muhammad Agus, (2017). Bonus Demografi Sebagai Peluang Dan Tantangan Pengelolaan Sumber Daya Alam di Era Otonomi Daerah. Genta Mulia.Vol.8 (20) Hal.90-99

Wang, C., Daneshmand, M., Dohler, M., Mao, X., Hu, R. Q., \& Wang, H. (2013). Guest Editorial - Special issue on internet of things (IoT): Architecture, protocols, and services. IEEE Sensors Journal, 13(10), 3505-3508. http://doi.org/10.1109/JSEN.2013.2274906.

Wahyudi, K. Andria., (2018). "Alat Peraga Jantung Manusia Berbasis Augmented Reality dengan Menggunakan Teknik 3D Object Tracking". Cotigo Smart Journal, 4(1): 46. 